Digital Press Social Sciences and Humanities

Integration of Developing Sea Border Area Through Archipelago Ecotourism in Anambas Archipelago Regency

Gerry Utama and Agus Hendratno

Proceeding of Indonesia Heritage Tourism Forum 2019 (IHTF 2019)

Dewi Pratika Ayu Dhira Pradati (eds) 


\title{
Integration of Developing Sea Border Area Through Archipelago Ecotourism in Anambas Archipelago Regency
}

\author{
Gerry Utama ${ }^{1, *}$, Agus Hendratno ${ }^{2}$ \\ 1 Department of Environmental Geography, Faculty of Geography, Universitas Gadjah Mada, Yogyakarta, Indonesia \\ 2 Department of Geological Engineering, Faculty of Engineering, Universitas Gadjah Mada, Yogyakarta, Indonesia \\ *e-mail: gerry.utama@mail.ugm.ac.id
}

\begin{abstract}
Indonesia's sea border areas have various problems besides economic inequality, limited access to infrastructure, and low human resources quality. This condition is very vulnerable to the sea border which acts as a gateway to the sovereignty of the country which has great natural resources potential which has not been developed optimally. Development of marine border area is one of the efforts to carry out sustainable development in managing and utilizing the potential of small islands and the foremost islands by integrating development planning through archipelago ecotourism approaches based on the characteristics of island typology, geology, geomorphology, coastal aquatic ecosystems, and sea, as well as socio-cultural characteristics. The research location is located in Anambas Archipelago Regency, Riau Archipelago Province, which has a vital role in geopolitical, geostrategic, and geo-economic conditions that are in the Indonesian Archipelago Sea Flow (ALKI 1) which is an international shipping lane and transportation. The purpose of this study is; 1 ) providing a model of developing the sea border area with an archipelago ecotourism approach; 2) inventorying potential information on tourist attraction objects, and 3) compiling directives and recommendations for planning and developing sustainable archipelago ecotourism. The method of this research was carried out by conducting an inventory of potential archipelago ecotourism which was then carried out with spatial analysis through data collection in the field and then processed through the compilation of spatial databases for the development of archipelagic ecotourism-based tourist attraction objects, after which spatial valuations related to projections of developing needs were carried out archipelago ecotourism related to supporting infrastructure needs by taking into account disaster risk aspects and environmental carrying capacity. The results of this study indicate that the archipelago ecotourism approach is a breakthrough in reducing the gap and underdevelopment of sea border areas through accelerating economic growth by managing and utilizing the potential of sustainable natural resources in the sea border area. The formation of new jobs based on the aspect of tourism is accompanied by an increase in the quality of human resources gradually through the opening of information on tourist attraction objects which are then managed by involving local communities.
\end{abstract}

\section{Keywords}

archipelago eco-tourism, sea border, sustainable development

\section{Introduction}

More than 2/3 of Indonesia's territory consists of seas which make Indonesian territory has a vast sea space and the largest archipelagic country in the world has more border areas consisting of sea space that stretches across Indonesia. State borders are one of the main manifestations of a country's sovereign territory that has a function and role in carrying out sovereignty territories, natural resources management, security, and territorial integrity (Muta'ali, 2014). Anambas Archipelago Regency is one of the regencies in Riau Islands Province. The location of this Regency which is directly bordered by neighboring countries such as Malaysia, Vietnam, and Thailand. The maritime location aspect which is in the Indonesian Archipelago Sea Current I (ALKI I) which has an important role in the geopolitical and geostrategic support of the Unitary State of the Republic of Indonesia which becomes international oceans traffic. The current planning of development is not following the typology of the existing regional characteristics. The urgency in linking regional development in integrating tourism planning in a sustainable manner through island- 
based ecotourism. Ecotourism development pays attention to aspects namely: 1) Landscape Management; 2) Socio-Cultural Characteristics, and 3) Conservation efforts (Tuwo, 2011, p. 29).

Development of the archipelago regions by integrating ecotourism planning is done by presenting spatial conditions related to public resources and system approach (Nugroho, 2011, p. 40). The innovation of archipelago ecotourism development needs to be one of the priorities in the Anambas Islands Regency. Williams and Lew (2014, p. 83) emphasize through effort; 1) physical constraints; 2) the nature tourist and attractions; 3) the state of tourism market; 4) planning and investment conditions, and; 5) levels of integration. The integration of the development of archipelagic ecotourism planning in the development of the sea border area in the Anambas Archipelago Regency is an effort to accelerate the growth of development in the sea border region in utilizing the potential of natural resources in a sustainable aspect. This study aims at: 1) providing a model of developing a sea border area with an archipelago ecotourism approach; 2) inventorying potential information on tourist attraction objects, and 3) compiling directives and recommendations for planning and developing sustainable archipelago ecotourism.

\section{Methods}

\subsection{Location Setting}

The determination of the location of this activity was carried out in Anambas Archipelago Regency in the Riau Archipelago Province. The location of this research was conducted by considering the characteristics of the typology of the region consisting of groups of islands and is a sea border area that is located on a strategic path.

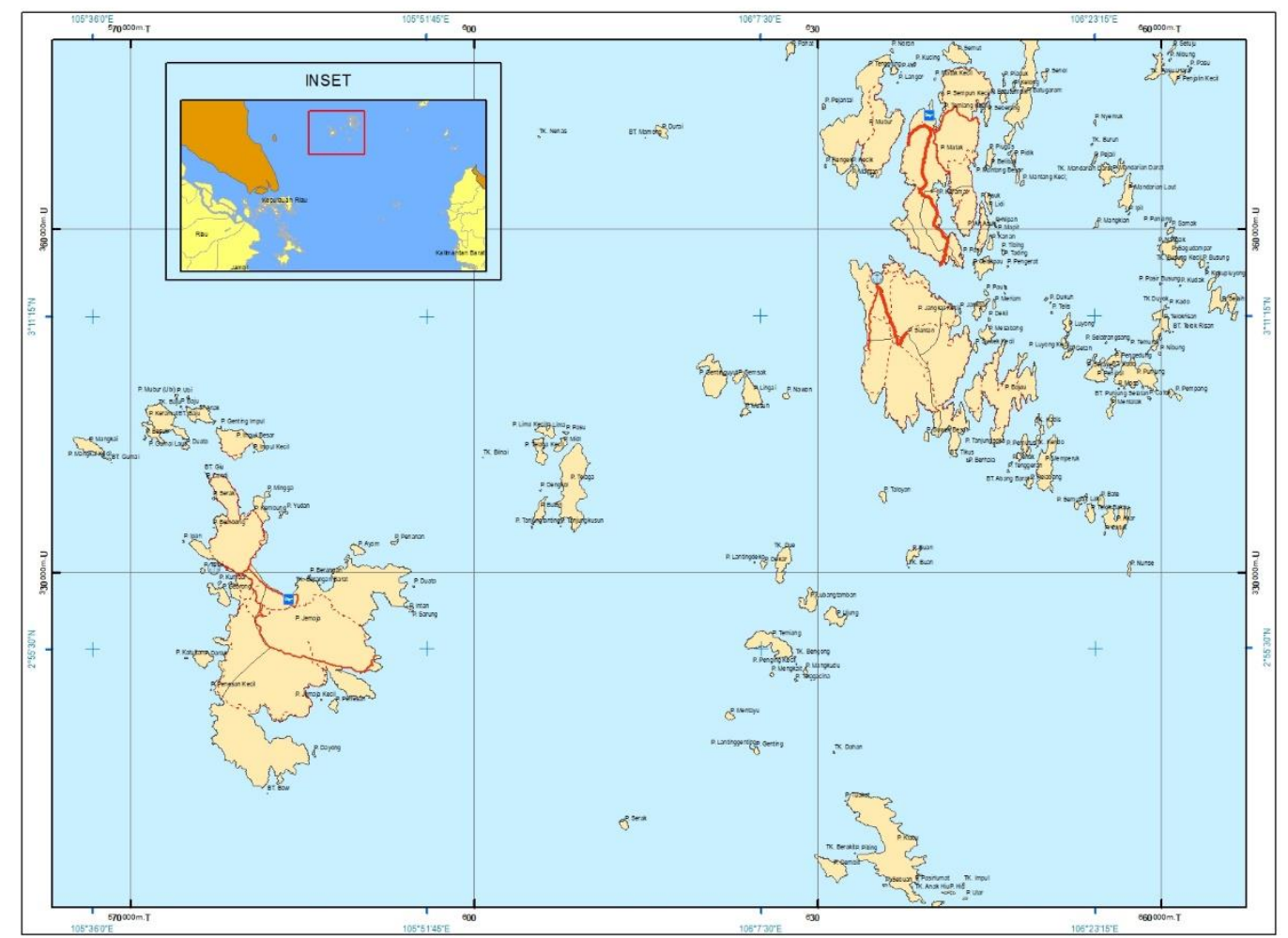

Fig. 1 Geographical Research Location 


\subsection{Data}

The data that are used in this analysis consists of primary data in the form of identification results during field activities on the potential of tourist attraction objects that can be developed. The data are then processed spatially which results in the spatial distribution of potential tourist attraction objects in the Anambas Islands Regency while the secondary data needed consist of spatial data.

Table 1 Spatial Data in Analysing Archipelago Tourism

\begin{tabular}{ll}
\hline \multicolumn{1}{c}{ Spatial Data } & \multicolumn{1}{c}{ Function } \\
\hline Administration & Information about administrative boundary \\
Landuse Features & Information characteristic of land use \\
Tourist Attraction Object & Information about tourist attraction object based on census and field data \\
Transportation & Information related route, transportation. \\
Landscape Features & Information about landform genetic processes \\
\hline
\end{tabular}

\subsection{Data Processing and Analysis}

Data processing is carried out by compiling spatial databases of the results of an inventory of tourist attraction locations that are used as a basis for analysis. The results are then presented in the form of a map of the distribution of potential locations for archipelago ecotourism development. The analysis was carried out by building integration of the reach or radius of the district capital which produced zones and priorities for the planning of the development of tourism areas. The preparation of archipelagic ecotourism priorities is carried out by taking into account the aspects of several parameters of the analysis of the archipelago ecotourism by using point density analysis to derived priority classes in archipelago ecotourism analysis. In addition, a comprehensive SWOT analysis needs to be one of the analytical methods used in supporting statistical analysis in the interrelation of efforts towards the integration of archipelago ecotourism planning.

\section{Finding and Discussion}

\subsection{Tourist Attraction Objects Inventorying}

The results of the analysis produce information about tourist attraction objects that are based on aspects of ecotourism conditions by taking into account characteristic information on coastal characteristics, reef conditions, and physical elements of the island that can be developed potential. Related to archipelago ecotourism. Information on the spatial distribution of tourist attraction objects based on islands ecotourism. Tourist attraction information emphasizes aspects of geomorphological characteristics, coastal typology, diversity of underwater biodiversity (Hall \& Page, 2016, p. 297). The high level of diversity of biodiversity results in the location of planned tourist attraction objects to the ecotourism of the islands which are spread throughout the Anambas Archipelago Regency.

The condition of tourist attraction objects found in Anambas Archipelago Regency is generally dominated by islands with white sand and rocky spread evenly in several islands. The proximity of the island caused many shallow waters which develop the coral reefs. In addition, an analysis in the archipelago ecotourism inventory was also carried out with due regard to the socio-cultural aspects related to maritime activities developing in the community. This analysis provides a perspective of the relationship to physical aspects and social conditions that exist in society. Some of the results of an inventory of tourist attraction objects in the form of historical aspects of the funeral of boat people who came from Vietnam. 

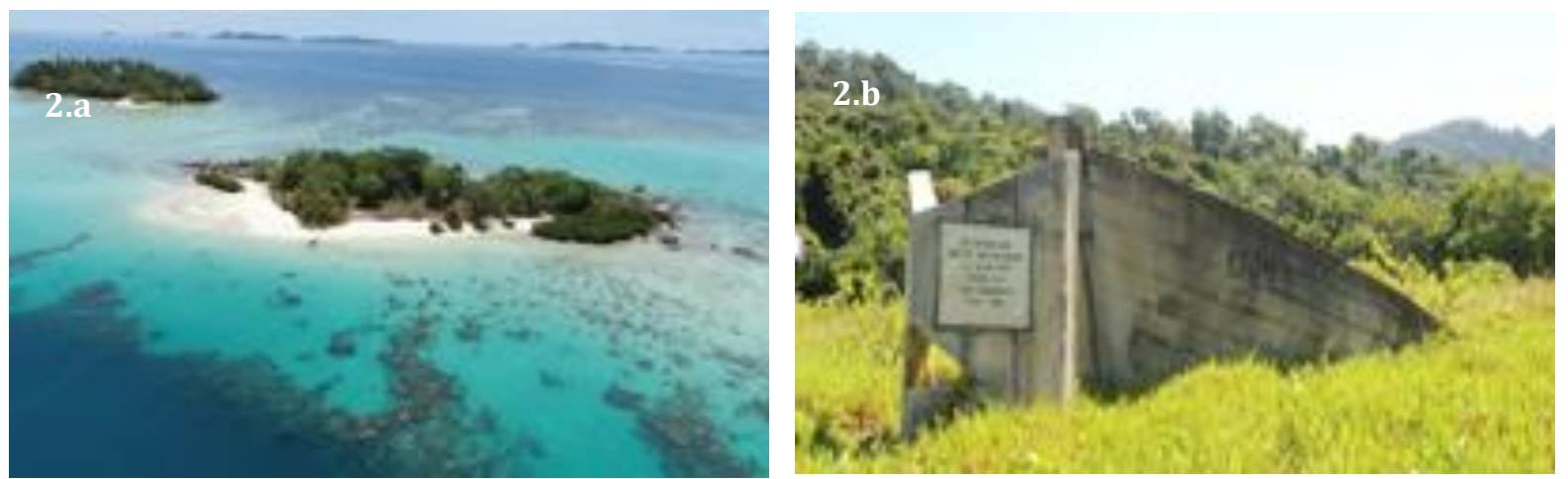

Fig. 2 Tourist Attraction In Anambas Regency 1; a Temawan island is one of natural tourist object in Anambas Archipelago Regency, b Monument of Vietnamese Boat who came to Anambas Archipelago Regency to avoid conflict in their country

Inventory of potential tourist attraction objects in the Anambas Archipelago Regency showed the results of an inventory of tourist attraction objects consisting of aspects of natural and cultural tourism that is evenly distributed in several districts in its regency.

Table 2 Total of Inventorying Tourist Attraction Objects in Anambas Archipelago Regency

\begin{tabular}{lrr}
\hline \multirow{2}{*}{ District } & \multicolumn{2}{c}{ Tourist Attraction Object } \\
\cline { 2 - 3 } & Natural & Cultural \\
\hline Jemaja & 21 & 9 \\
East Jemaja & 7 & 3 \\
Palmatak & 22 & 5 \\
Siantan & 3 & 3 \\
South Siantan & 28 & 3 \\
Central Siantan & 5 & 4 \\
East Siantan & 21 & 4 \\
\hline \multicolumn{1}{c}{ Total } & 107 & 31 \\
\hline
\end{tabular}

The results of the inventory showed that the existence of natural tourism by taking into account the elements of the condition of the characteristics of the island, the existence of coral reefs, and the condition of the landform of the coast are very large in existence when compared with the results of data collection conducted on cultural tourism in the community. Data from the results of the inventory can be a reference or source of data on the development of archipelago ecotourism in the Anambas Archipelago Regency.

Generally, the condition of tourist attraction objects on aspects of the characteristics of natural attractions has elements of potential for complex development so that in the identification of tourist attraction objects can be found in more than a few locations of development of tourism areas that can be developed more comprehensively. The elements of cohesiveness and variations in landform characteristics have unique valuations in the effort to develop tourism. In addition, the aspect of distance or accessibility of some locations has a short distance. This has become one of the important points in making efforts to arrange transportation routes, especially sea transportation that connects each tourist attraction. 


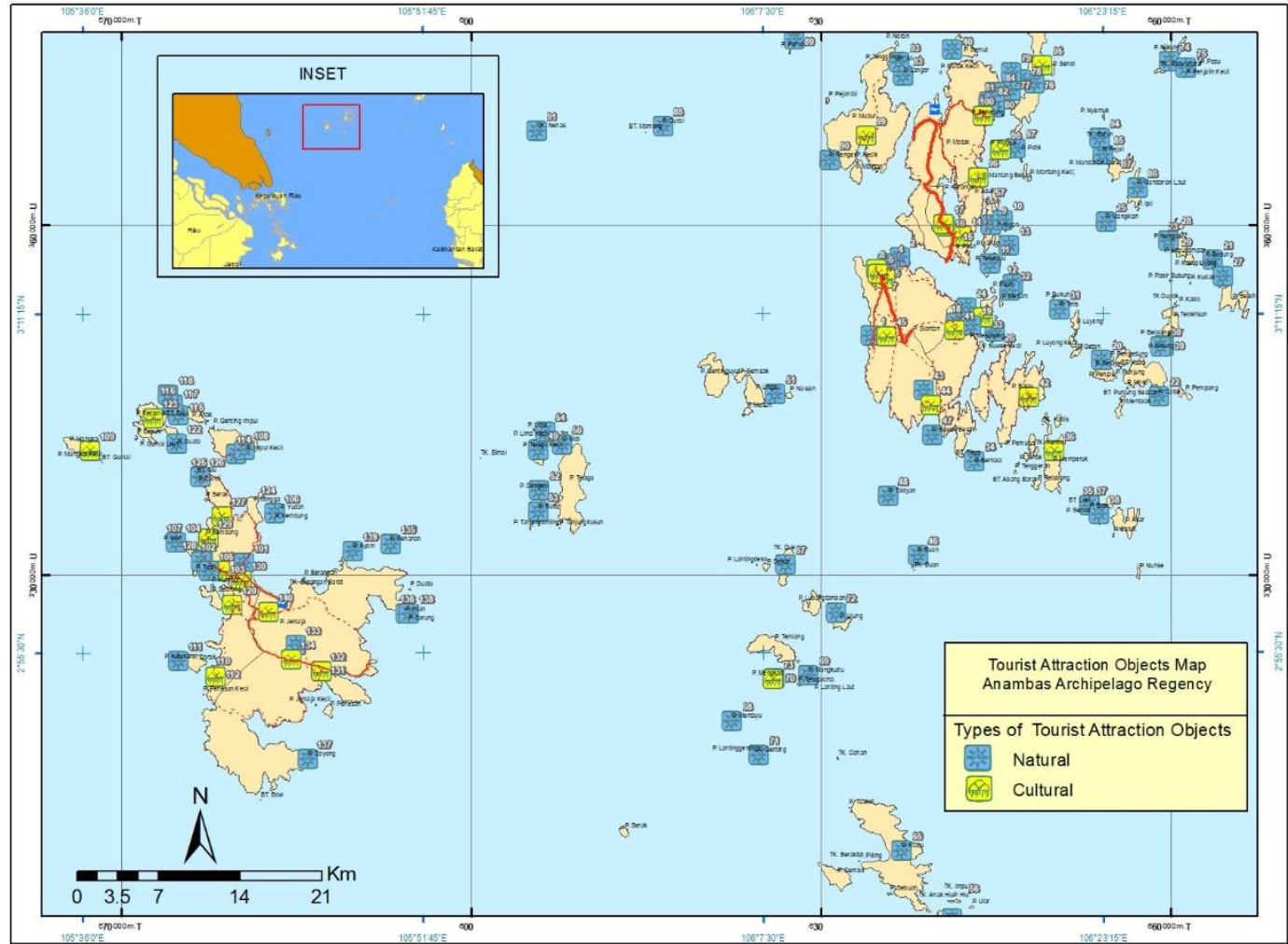

Fig. 3 Tourist Attraction Objects Map of Anambas Archipelago Regency

\subsection{Archipelago Tourism}

The development of archipelago ecotourism is one of the efforts in providing tourism approach by looking at aspects of the condition of the potential resources owned by the islands. This approach involves a study of the exotic elements of the archipelago. This approach is one of the breakthroughs in making efforts to approach development in the sea border region of the Republic of Indonesia because generally, it is an area that has the least developed areas. The integration of regional development can also be done by utilizing the information contained in tourist attraction objects so that the direction of development. Information on the development of archipelago ecotourism is done by taking into account aspects of geomorphological conditions that characterize the uniqueness that can be developed into a tourist activity. Geomorphology is the science of landforms both above the surface of the Earth and below the surface of the sea that forms into a series of landform configurations (Verstappen, 1983).

The archipelago ecotourism approach is one of the hallmarks of managing sustainable tourism development in the sea border area which has a strategic role in the sovereignty of the country's territory. Goffi \& Cucculelli (2014) provide an instrument model for sustainable tourism management, while the archipelago ecotourism approach model provides a solution to the efforts of more complex problems occurring in Indonesia where the sea border area is a disadvantaged region. Management and utilization of natural resources are less than optimal, high levels of poverty, and then limited infrastructure and transportation conditions. This is a challenge in solving problems in the sea border area by using the archipelago ecotourism approach to focus on the role of community participation in optimizing and managing regional resources to be developed into sustainable tourism destinations.

The more complex and complete a landform that can be developed into a tourist attraction, the greater the potential for development, as well as the structuring of the tourist area by involving the role of the community. In addition, the greater and wider employment opportunities are also formed in the sea border area, which so far the options for working are very limited in the border area. This condition has a big impact on the status of the economic status of the people who are in the area of tourism development. 


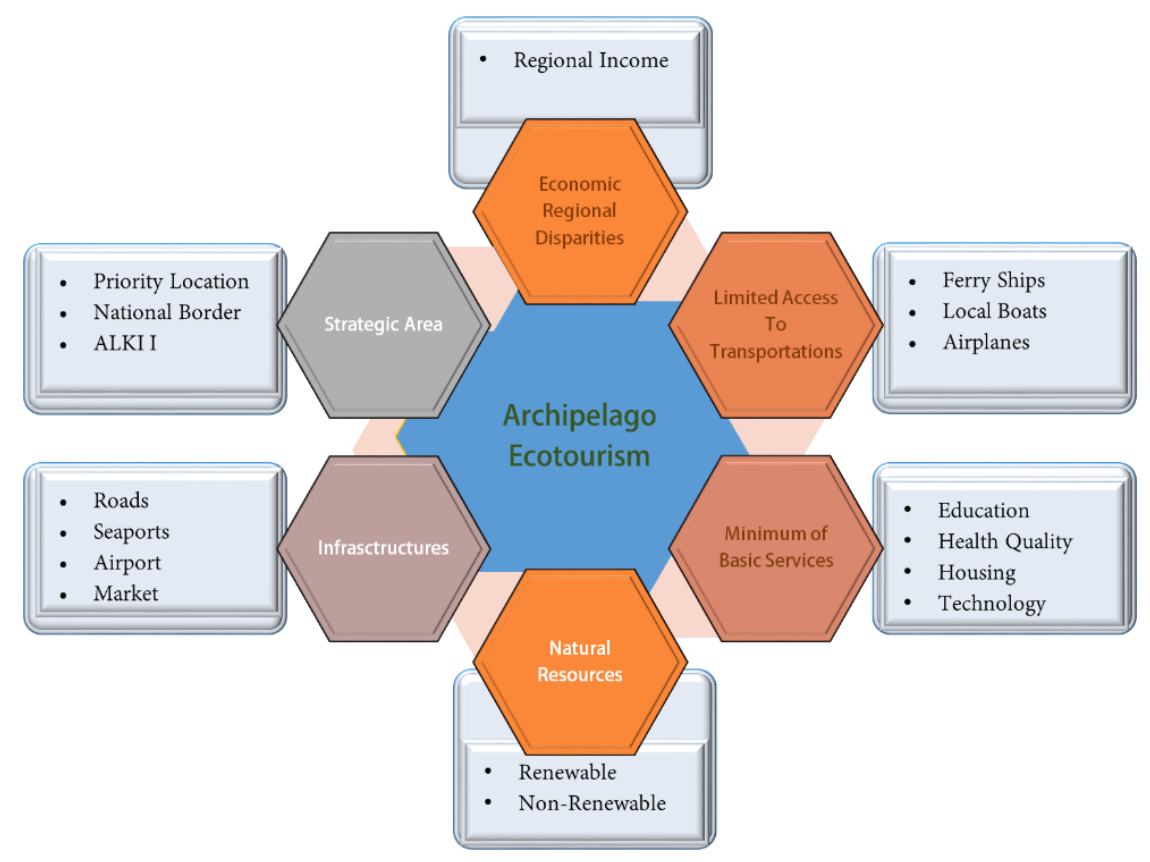

Fig. 4 The framework of Archipelago Ecotourism Management

\subsection{SWOT Analysis in Regional Development Planning Based on Archipelago Ecotourism Perspective}

The use of SWOT (Strength, Weakness, Opportunities, Threat) analysis provides a more detailed description of the challenges in developing island ecotourism in the Anambas Archipelago Regency. SWOT is used to describe more integrated factors of the component elements of SWOT which provide convenience in planning and developing island ecotourism.

Table 3 SWOT Analysis in Developing Archipelago Ecotourism

\begin{tabular}{|c|c|}
\hline Strength & Weakness \\
\hline 1. Natural landscape & 1. Lack of promotion \\
\hline 2. Cleanliness & 2. Expensive \\
\hline 3. Strategic Location & 3. Low Accessibility \\
\hline \multirow[t]{2}{*}{ 4. Underwater Landscape } & 4. Language Barrier \\
\hline & 5. Un-well educated \\
\hline Opportunities & Threat \\
\hline 1. New and Improving Infrastructures & 1. Climate Change \\
\hline 2. New Job Market & 2. Cultural Lack \\
\hline 3. High Income & \\
\hline
\end{tabular}

The description of the SWOT analysis provides an overview of the strength aspects of the potential offered, is the condition of landforms that are still natural and clean, in addition to the existence of scattered underwater ecosystem variations is a strength factor that is owned as a first step in building island ecotourism. The challenge in the aspect of weakness is the lack of massive promotion which is one of the biggest weaknesses in the sea border area. Besides the high cost and low accessibility, the tourist interest to visit is very low, besides that the low level of education also impacts the condition of limited 
accommodation facilities so that it affects the service aspects. Threats to the development of archipelago ecotourism are climate factors and the lack of culture originating from local residents who are not yet open to tourism.

\section{Conclusion}

The development of archipelago ecotourism is one of a way to accelerate development in the sea border area. The results of the inventory show the number of potential natural-based tourist attraction objects found as many as 107 locations and cultural tourism locations totaling 31 locations that can be developed into tourist attraction objects based on archipelago ecotourism perspective. The archipelago ecotourism approach provides a solution to the description of the conditions of the complex problems found in the sea border region by taking into account the sustainable aspects.

The integration of regional development at sea borders can be done by integrating with tourist destinations that can be developed so that infrastructure development and planning can be synergized with the needs and goals of regional development that provide benefits to the community. Promoting massive tourism is an effort to introduce Anambas Archipelago Regency by emphasizing the ecotourism branding of the exotic archipelago.

Acknowledgments Thank you very much to the Government of Anambas Archipelago Regency through Centre Studies of Tourism Universitas Gadjah Mada for the cooperation project "Designing of Tourism Masterplan in Anambas Archipelago Regency.

\section{References}

Goffi, G., \& Cucculelli, M. (2014). Components of destination competitiveness. The case of small tourism destinations in Italy. International Journal of Tourism Policy, 5(4), 296. https://doi.org/10.1504/IJTP.2014.068035

Hall, C. M., \& Page, S. J. (2016). The Geography of Tourism and Recreation Environment, Place and Space. New York: Routledge.

Muta'ali, L. (2014). Border Area Development. Yogyakarta: Publishing Agency of Faculty of Geography, UGM.

Nugroho, I. (2011). Ecotourism and Sustainable Development. Yogyakarta: Pustaka Pelajar.

Tuwo, A. (2011). Coastal and Sea Ecotourism Management. Surabaya: Brilian International.

Verstappen, T. H. (1983). Geomorphology: Geomorphological Survey for Environmental Development. Amsterdam: Elsevier.

Williams, S., \& Lew, A. L. (2014). Tourism Geography: Critical Understanding of Place, Space and Experience. New York: Routledge. 